УДК 339.13

DOI: 10.17277/voprosy.2016.01.pp.052-057

\title{
MARKETING RESEARCH FOR A RETAIL CHAIN IN TAMBOV
}

\author{
N. V. Dyuzhenkova, N. V. Molotkova, A. S. Tarmosina \\ Tambov State Technical University, Tambov \\ Reviewed by Doctor of Economic Sciences, \\ Professor S. P. Spiridonov
}

Keywords: commercial enterprise; consumer; marketing research; survey.

\begin{abstract}
The authors explore the problem of marketing research for a retail commercial enterprise. In the paper, the authors describe the results of the research carried out for a local retail chain. The retailor has operated through more than 20 convenience stores and several supermarkets in the Tambov region for more than 10 years. The authors conducted a survey research by administering questionnaires to customers. The purpose of the study was to find out consumer visit frequency, ways of informing consumers about current promotions, reasons for choosing the store, consumer opinion on the need for changes in the supermarket, frequency of purchasing certain goods, how customers get to the store, their opinion on customer service and prices, the degree of customer satisfaction. In addition, we obtained data on such common features as gender, age and social status of consumers. The findings are detailed in numbers or percentages and summarized in charts. Using the information obtained through the marketing research, the authors have made conclusions and have given recommendations for the retail chain.
\end{abstract}

Marketing research conducted for a commercial enterprise helps the company to evaluate its position in the market and to identify its strengths and weaknesses. In addition, marketing research is a form of research that focuses on understanding of behavior, desires and preferences of consumers, competitors and markets [1]. In this regard, marketing research involves analyzing customers, competitors, products, prices, merchandising, promotion and internal environment.

Дюженкова Наталия Владимировна - кандидат экономических наук, доцент кафедры «Коммерция и бизнес-информатика»; Молоткова Наталия Вячеславовна - доктор педагогических наук, профессор, первый проректор ТамбГТУ, e-mail: tstu@admin.tstu.ru; Тармосина Анастасия Сергеевна - студентка, ТамбГТУ, г. Тамбов. 
Marketing information can be gathered in different ways, which include surveys, observations, experiments and panels [2]. As a part of marketing research, a survey involves asking people about their positions on certain issues related to the firm activity. A survey can be mass or specialized, single or group, blanket or selective, with free or structured scheme, disposable or reusable, oral (interviews) or written (questioning) [3]. In the context of marketing, an observation is a direct monitoring of people and environment. An experiment involves finding the influence of one or more independent variables on one or more dependent variables. A panel as a form of research is considered as a multiple poll of a targeted consumer group at regular intervals or monitoring of the store sales activity.

We consider the findings of marketing research conducted for a supermarket of a large retail network operating through supermarkets and convenience stores in the territory of the Tambov region from 2003. The network consists of 25 convenience stores and 6 supermarkets. The number of employees of the company is about 1,500 people.

We developed a questionnaire to study the views of consumers on the activities of the studied commercial enterprise. The object of observation was a supermarket located in the northern part of Tambov. The unit of observation as well as accounting units were consumers. The observation period lasted for 2 hours from 16:00 to 18:00 on a summer weekday. On grounds of the time of registration of facts this observation was discrete (one-time), on grounds of the degree of coverage of population units it was selective. Respondents were interviewed on a pre-prepared questionnaire consisting of 13 closed questions with one or more options.

We obtained information on consumer visit frequency, ways of informing consumers about current promotions, reasons for choosing the store, consumer opinion about the need for changes in the supermarket, the frequency of purchasing certain goods, the way consumers use to get to the store, opinion on customer service and prices, the degree of customer satisfaction. Also, data were obtained on such common features as gender, age and social status of the consumer.

The sample for the survey was as follows: by gender $31 \%$ of respondents were male and $69 \%$ were female, by age $19 \%$ of respondents were under the age of 20 years, $31 \%$ were between the ages of 20 to 30 years, $6.5 \%$ were between the ages of 30 to 40 years, $6.5 \%$ were aged from 40 to 50 years, and $37 \%$ were people over the age of 50 years old. Such a ratio of age groups could be explained by the fact that the survey was conducted during the daytime when the majority of people of working age was at work. Conversely, people aged younger than 30 years and older than 50 are often students or retired and they can visit the store at daytime. The fact of conducting the survey in the daytime also affected the structure of the respondents by social status, namely $43.5 \%$ out of all respondents were students, $25 \%$ were retired people, $18.5 \%$ were employees, $6.5 \%$ were entrepreneurs and $6.5 \%$ were representatives of social groups not accounted in the questionnaire. 


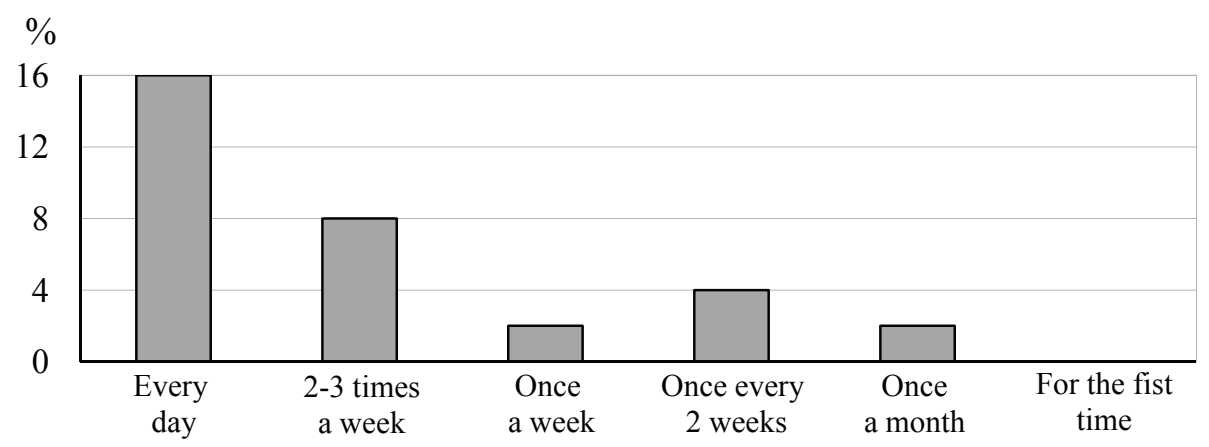

Fig. 1. Customer visit frequency to the investigated store

As can be seen from Fig. 1, half of the respondents visit the studied store every day, a quarter of the surveyed customers make a purchase in the supermarket 2 or 3 times a week, $12 \%$ of respondents visit the supermarket once every 2 weeks, $6.5 \%$ of respondents visit the store once a week and once a month, respectively. At the time of the survey, all customers made repeat purchases. These results can be explained by the fact that the store is located, firstly, in a residential area of the city and, secondly, it can be easily reached by public transport. The supermarket is conveniently located next to the bus stop, making it easy for working population to drop in on the way home. Proximity to residential area explains the frequency of visits (every day or at least 2 or 3 times a week).

Figure 2 shows the reasons affecting the choice of the supermarket. Most shoppers choose this supermarket because of its convenient location to their place of work or residence, $19 \%$ of the people surveyed choose the store accidentally, and $6.5 \%$ of the respondents choose this supermarket because of low prices, high quality goods, good service and a large range of products, respectively.

It was found that more than a half of the respondents do not notice information about in-store promotions, $25 \%$ of the respondents get information about promotions and discounts from posters and price tags, and 19\% get it from the media. This is due to the fact that shoppers choose this supermarket for

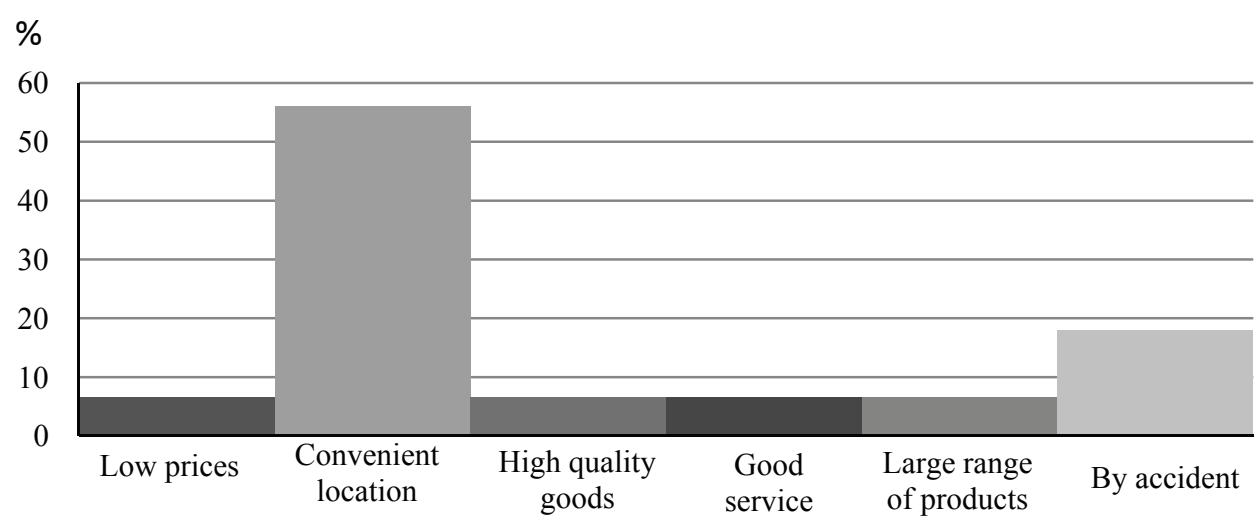

Fig. 2. Reasons for choosing the store 
various reasons not related to advertising and other marketing activities of the company. The store is popular because of its location in close proximity to a large number of residential buildings. According to the majority of the respondents, prices in the store do not differ from those of other retailers or are slightly lower. This means that the majority of consumers do not need additional stimulation of the purchase by the commercial enterprise. However, the firm should pay attention to the policy in the field of advertising and marketing to raise its competitiveness.

It is worth noting that the firm carries out certain marketing campaigns to attract buyers. Such promotions are associated with various holidays and significant dates in the cultural, religious and social life throughout the year. For example, there are some pre-holiday discounts on certain groups of products, which are often purchased as gifts on certain holidays. In addition, discounts on meat-free products are offered during fasting. These are just a few examples of the extensive activity of the company in the field of marketing, however, the survey data show that consumers of the supermarket are not aware of the advertising information or receive it from price tags and posters in the store, and only a small number of customers are informed through the media.

About a third part of the surveyed customers would like to change the store parking lot and make it more comfortable. And about a third part of the respondents want to speed up the service, $12.5 \%$ of respondents want to improve the quality of sellers work and to increase the amount of promotions held in the store and to improve the merchandise, respectively. It is necessary to monitor the number of concurrent cash registers more carefully to increase the speed of service.

Figure 3 shows buying patterns of consumers of the supermarket. Consumers most often buy vegetables and fruits $(62.5 \%$ of people surveyed chose this option) and bakery products $(56 \%)$. Less popular groups of products are dairy products $(50 \%)$, groceries $(37.5 \%)$, sausage products $(31 \%)$, beverages (25\%), alcohol (19\%), semi-finished products $(12.5 \%)$ and cheese $(6.5 \%)$, almost none of the respondents purchase household goods in the studied shop.

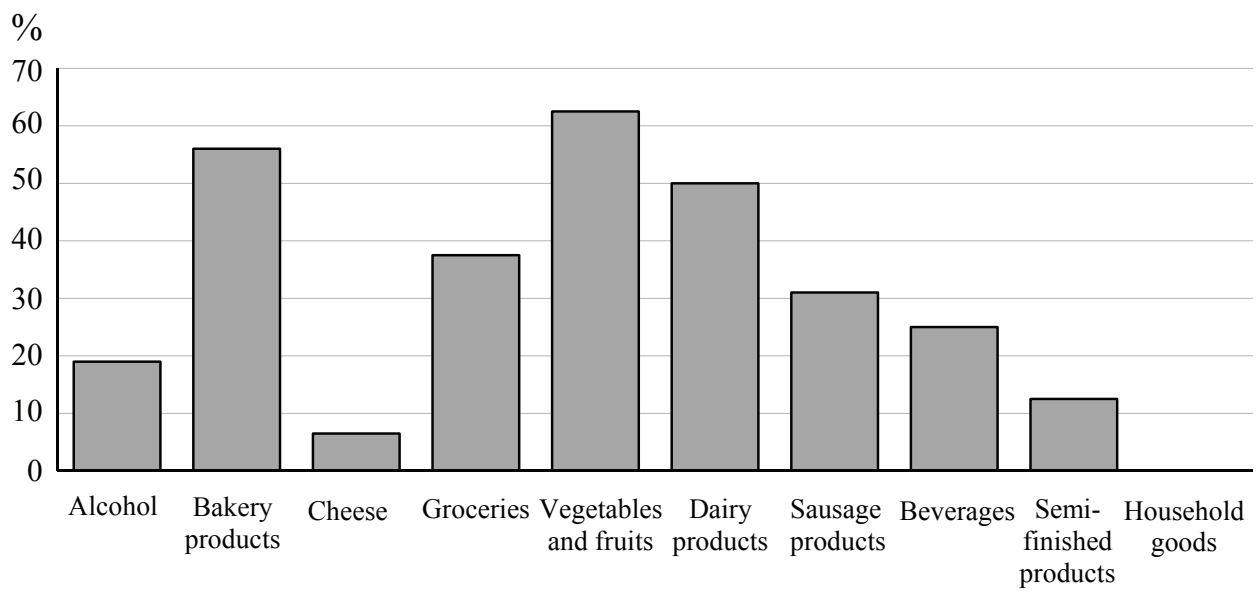

Fig. 3. Consumer buying patterns in the studied supermarket 
Such a buying pattern can be explained by the fact that most consumers make purchases at the store every day or two or three times a week and buy basic consumer goods and highly perishable foodstuffs, namely, vegetables and fruits, bakery and dairy products. On the basis of this data it can be concluded that the company should direct their marketing efforts to increase the demand for such products as semi-finished products, alcohol, cheese and household goods.

The survey revealed that the overwhelming majority of the respondents get to the store on foot, $12.5 \%$ of the surveyed go by public transport, and $6.25 \%$ of the respondents use personal transport. This is due to the fact that the targeted audience is presented mostly by people working and living in the vicinity of the store.

Data obtained through monitoring revealed the opinion of shoppers on the customer service and prices. More than a third of the customers described the staff of the supermarket as helpful, and another third said the staff were not always helpful. Several people found it difficult to answer the question about the quality of the staff and a few respondents said that the staff were not helpful. Slightly less than half of the customers said that prices in the investigated retailer were not different from those in the consumer market as a whole. About a third of shoppers found the prices in the studied store lower than in other shops, and about a quarter of the surveyed believed that prices were higher than in the other shops.

The study of the degree of customer satisfaction showed that the vast majority of the respondents purchased all planned products when making a purchase at the store, several people did not purchase all planned products, and $6 \%$ of the surveyed people did not satisfy their needs.

Half of the respondents spent between $500-1000$ rubles, about a third of the customers spent 200 to 300 rubles. By $6.25 \%$ of the surveyed said that they spent less than 100 rubles and from 100 to 150 rubles respectively, none of the respondents usually spends more than 1000 rubles. This is explained by the fact that the studied commercial enterprise is aimed at small and medium purchases made mostly daily or two or three times per week, as noted above.

The gathered information indicated a positive attitude of the majority of customers to the supermarket, but the firm should take actions to improve its customer service. In addition, the company should analyze its pricing policy more carefully and probably make some changes to it.

\section{References}

1. Denisova A.L., Dyuzhenkova N.V., Molotkova N.V. [The study of consumer behavior and assessment of commercial activity of retailers in Tambov], Marketing $v$ Rossii $i$ za rubezhom [Marketing in Russia and Abroad], 2007, no. 1, pp.44-57. (In Russ.)

2. Golubkov E.P. [Marketing researches], Moscow: Finpress, 2008. (In Russ.)

3. Anurin V., Muromkina I., Evtushenko E. [Marketing studies of the consumer market], St. Petersburg: Piter, 2006. (In Russ.) 


\section{Список литературы}

1. Денисова, А. Л. Изучение поведения покупателей и оценка коммерческой деятельности предприятий розничной торговли г. Тамбова / А. Л. Денисова, Н. В. Дюженкова, Н. В. Молоткова // Маркетинг в России и за рубежом. - 2007. № 1. - С. $44-57$.

2. Голубков, Е. П. Маркетинговые исследования / Е. П. Голубков. - М. : Финпресс, 2008. - 496 с.

3. Анурин, В. Маркетинговые исследования потребительского рынка / В. Анурин, И. Муромкина, Е. Евтушенко. - СПб. : Питер 2006. - 272 с.

\section{Маркетинговые исследования для сети розничных торговых предприятий г. Тамбова}

\section{Н. В. Дюженкова, Н. В. Молоткова, А. С. Тармосина}

ФГБОУ ВПО «Тамбовский государственный технический университет», г. Тамбовский

Ключевые слова: маркетинговое исследование; опрос; потребитель; торговое предприятие.

Аннотация: Рассмотрена проблема маркетинговых исследований в области розничной торговли. Приведены результаты исследования, проведенного для сети розных торговых предприятий, осуществляющих свою деятельность на территории Тамбовской области.

(C) Н. В. Дюженкова, Н. В. Молоткова, А. С. Тармосина, 2016 